\title{
EXPERIMENTAL RESEARCH INTO THE EFFECT OF HYPERBARIC EXPOSURES
}

\author{
BADANIA DOŚWIADCZALNE NAD STRESUJĄCYM WPEYWEM HIPERBARII
}

\section{ЭКСПЕРИМЕНТАЛЬНЫЕ ИССЛЕДОВАНИЯ СТРЕССОГЕННОГО ВЛИЯНИЯ ГИПЕРБАРИИ}

\section{EXPERIMENTE ZUM STRESSENDEN EINFLUSS DER HYPERBARIE}

\section{ESTUDIOS EXPERIMENTALES SOBRE LOS EFECTOS ESTRESANTES DE LA HIPERBARIA}

\author{
Augustyn Dolatkowski, Tadeusz Doboszyński, Bogdan Łokucijewski \\ Department of Maritime Medicine of the Military Medical Academy \\ Katedra Medycyny Morskiej WAM

\section{StRESZCZENIA / ABStRACTS}

Numerous research works indicate that staying in a hyperbaric environment is a stressor. We have undertaken studies using an animal model to determine the effect of hyperbaria on adrenocortical secretion and the level of adrenal ascorbic acid (a.a.a). The research was conducted on 70 male hooded rats, which were divided into groups and subjected to hyperbaric air and oxygen at an overpressure of 1 and 3 atn, with some of the animals being additionally burdened with physical effort (swimming)

It was found that short-term exposures (30 minutes) of rats to hyperbaric conditions caused a decrease in the content of a.a.a. With a prolonged (3-hour) exposure to $3 \mathrm{~atm}$ air the a.a.a. content returns to a normal level. A reduction in the a.a.a. content indicates the presence of stress in hyperbaric conditions in the rat, however, it does not allow to determine its intensity with the method used in the study.

Keywords: overpressure, animal model, stressor, ascorbic acid.

W licznych pracach badawczych przebywanie w środowisku hiperbarycznym wskazywane jest jako stresor. Podjęliśmy badania z zastosowaniem modelu zwierzęcego w celu określenia wpływu hiperbarii na sekrecję kory nadnerczy i poziom nadnerczowego kwasu askorbinowego. Badania przeprowadzono na 70 samcach szczurów kapturowych które podzielono na grupy i poddano działaniu hiperbarii powietrznej i tlenowej o nadciśnieniu 1 i 3 atn, część zwierząt dodatkowo została obciążona wysiłkiem (pływanie)

Stwierdzono iż krótkotrwała (30 minut) ekspozycja szczura na hiperbarię powoduje obniżenie zawartości n.k.a. Przy przedłużonej (3-godzinnej) ekspozycji na 3 atn powietrza zawartość n.k.a. wraca do normy. Obniżenie zawartości n.k.a. wskazuje na występowanie u szczura stresu w warunkach hiperbarii, jednak nie pozwala na określenie jego nateżenia stosowana w badaniu metoda.

Słowa kluczowe: nadciśnienie, model zwierzęcy, stresor, kwas askorbinowy.

В многочисленных научных работах пребывание в гипербарической среде указывается в качестве стрессора. Мы провели исследования с использованием животной модели с целью определения влияния гипербарии на секрецию коры надпочечников и уровень надпочечниковой аскорбиновой кислоты. Исследование было проведено на 70 самцах лабораторных крыс, которые были разделены на группы и подвержень воздействию воздушной и оксигенной гипербарии с давление 1 и 3 атмосферы, часть животных была дополнительно физически нагружена (плавание).

Установлено, что кратковременная (30 минут) экспозиция крысы на гипербарию вызывает снижение содержания надпочечниковой аскорбиновой кислоты. При длительной (3-часовой) экспозиции на 3 атм. воздуха содержание надпочечниковой аскорбиновой кислоты возвращается в норму. Снижение содержания надпочечниковой аскорбиновой кислоты указывает на появление у крысы стресса в условиях гиперабарии, однако не позволяет определить его силу методом, использованным в исследовании.

Ключевые слова: повышенное давление, животная модель, стрессор, аскорбиновая кислота.

ARTICLE INFO

PolHypRes 2017 Vol. 61 Issue 4 pp. 43 - 48

ISSN: 1734-7009 elSSN: 2084-0535

DOI: 10.1515/phr-2017-0021

Pages: 6 , figures: 2 , tables: 1

page www of the periodical: www.phr.net.pl

Publisher

Polish Hyperbaric Medicine and Technology Society
Typ artykułu: oryginalny

Original article

Opublikowano w Gdańskim Roczniku Naukowym 1969

Przyjęto do druku w PHR 19.08.2017r 
In zahlreichen Forschungsarbeiten wurde der Aufenthalt in einer hyperbaren Umgebung als Stressor angegeben. Wir haben Untersuchungen mit einem Tiermodell aufgenommen, um den Einfluss von Hyperbarie auf die Sekretbildung der Nebennierenrinde und das Niveau der Askorbinsäure der Nebenniere festzustellen. Die Untersuchung wurde an 70 Farbratten-Männchen durchgeführt, die in Gruppen aufgeteilt und der Wirkung von Luft- und Sauerstoffhyperbarie mit einem Überdruck von 1 und 3 atn ausgesetzt wurden, ein Teil der Tiere wurde zusätzlich mit Anstrengung (Schwimmen) belastet. Es wurde festgestellt, dass eine kurzfristige (30minütige) Hyperbarie-Exposition der Ratten eine Minderung des NKA-Gehalts hervorruft, Bei verlängerten (dreistündiger) Exposition auf 3 atn Luft kehrte der NKA zur Norm zurück. Die Minderung des NKA-Gehalts verweist darauf, dass bei der Ratte Stress unter den Bedingungen der Hyperbarie auftritt, lässt allerdings nicht dessen Intensität feststellen, die in der Untersuchung mit der Methode angewandt wurde. Schlüsselwörter: Überdruck, Tiermodell, Stressor, Askorbinsäure.

En muchos trabajos de investigación, la permanencia en un entorno hiperbárico se indica como un factor estresante. Hemos llevado a cabo una serie de pruebas utilizando un modelo animal para determinar el efecto de la hiperbaria sobre la secreción cortical suprarrenal y los niveles suprarrenales de ácido ascórbico. El estudio se llevó a cabo en 70 machos de ratas con capucha que fueron divididos en grupos y sometidos a hiperbaria de aire y de oxígeno a una presión de 1 y 3 atn, algunos animales fueron sometidos a un sobreesfuerzo adición (natación).

Se comprobó que la exposición a corto plazo (30 minutos) de la rata a la hiperbaria provocó una reducción de los niveles suprarrenales de ácido ascórbico. Durante una exposición prolongada ( 3 horas) a 3 atn de aire los niveles suprarrenales de ácido ascórbico volvieron a la normalidad. La reducción de los niveles suprarrenales de ácido ascórbico apunta a la aparición de estrés en ratas en condiciones hiperbáricas, aunque no permite determinar su concentración debido al método utilizado en el estudio.

Palabras clave: hipertensión, modelo animal, factor estresante, ácido ascórbico. 


\section{WSTĘP}

Uważa się, że hiperbaria może stanowić czynnik stresujący na równi $\mathrm{z}$ innymi stresorami, takimi jak zimno, hałas, wibracje czy bodźce emocjonalne $[1,3,4,10]$. W wyniku oddziaływania hiperbarii i powstałej reakcji alarmowej może nastąpić wzmożenie aktywności układu przysadkowo-korowonadnerczowego, wzrost sekrecji kory nadnerczy z obniżeniem się stężenia nadnerczowego kwasu askorbinowego (n.k.a.). Kora nadnerczy szczura wydziela głównie kortykosteron [5], do którego biosyntezy niezbędny jest kwas askorbinowy i dlatego jego stężenie $\mathrm{w}$ nadnerczach obniża się w wypadku zwiększonej produkcji hormonów korowych.

W zależności od rodzaju działającego czynnika spadek n.k.a. przebiega $\mathrm{z}$ różną szybkością, przy czym wielkość tego spadku jest proporcjonalna do natężenia stresu. Ponieważ zmiany stężenia n.k.a. u szczurów uważa się za specyficzną i ilościową ocenę aktywacji osi przysadkowo-nadnerczowej w warunkach ostrego stresu $[12,14,20]$ zastosowaliśmy oznaczenie n.k.a. $\mathrm{w}$ warunkach hiperbarii powietrznej i tlenowej jako miernik obciążenia ustroju.

\section{MATERIAE I METODY}

Badania przeprowadzono na 70 szczurach kapturowych, jednorodnych samcach o ciężarze 180-220 g. Zwierzęta przebywały stale $\mathrm{w}$ temperaturze około $24^{\circ} \mathrm{C}$, otrzymywały standardową dietę hodowlaną i wodę ad libitum. Do badań użyto zwierząt przebywających $\mathrm{w}$ hiperbarii $\mathrm{w}$ warunkach spokoju lub też poddanych wyczerpującemu wysiłkowi fizycznemu (test pływania) $[7,13,14]$. Badania przeprowadzano w doświadczalnej komorze ciśnieniowej dla zwierząt, która napełniano powietrzem i podnoszono ciśnienie do 1-3 atn. Wentylacja komory pozwalała utrzymać stężenie $\mathrm{CO}_{2}$ na wystarczająco niskim poziomie $(0,3 \%)$. Zwierzęta pozostające $\mathrm{w}$ spoczynku poddano nadciśnieniu powietrza równemu 1 i 3 atn przy czasie ekspozycji 30 min. i 3 godz. Zwierzęta pływające pozostawały pod ciśnieniem 1 i 3 atn $\mathrm{w}$ czasie uzależnionym od ich zdolności wysiłkowej: 40 minut dla 1 atn i 20 minut dla 3 atn.

Metodykę oznaczania n.k.a. podano w pracy opublikowanej wcześniej w „Medycynie Pracy” [13]. Grupę kontrolną stanowiły szczury, które przebywały przez 1-3 godziny w komorze doświadczalnej w spoczynku bez stosowania nadciśnienia.

\section{WYNIKI}

Uzyskane wyniki przedstawia tabela 1 oraz rysunki 1 i 2.

\section{INTRODUCTION}

It is believed that hyperbaria may constitute a stress factor on an equal footing with other stressors such as cold, noise, vibrations or emotional stimuli $[1,3,4,10]$. As a result of hyperbaria and the occurred alarm reaction, an increased activity of the pituitaryadrenocortical may be noted alongside an increase in the adrenocortical secretion and a reduction in the concentration of adrenal ascorbic acid (a.a.a.). The adrenal cortex in rats mainly secretes corticosterone [5] the biosynthesis of which requires the presence of ascorbic acid, that is why its concentration in the adrenal glands decreases as the production of cortical hormones increases.

Depending on the trigger, the decrease in the amount of a.a.a. occurs at varying rates, with its degree being proportional to the intensity of stress. Because changes in the concentration of a.a.a. are believed to constitute a specific and quantitative assessment of the activation of the pituitary-adrenal axis under acute stress $[12,14,20]$ we used the a.a.a. determination in hyperbaric air and oxygen conditions as a measure of system burden.

\section{MATERIAL AND METHODS}

The study was conducted on 70 hooded rats, uniform males with the weight of 180-220 g. The animals were kept continuously in a temperature of approximately $24^{\circ} \mathrm{C}$ and fed ad libitum with a standard diet and water. Animals used in the study were subjected to hyperbaric conditions while at rest or being exposed to exhaustive physical exercise (swimming test) $[7,13,14]$. The tests were carried out in an experimental pressure chamber for animals, which was filled with air with the pressure raised to 1-3 atn. The chamber ventilation allowed to keep the $\mathrm{CO}_{2}$ concentration at a sufficiently low level $(0.3 \%)$. Animals remaining at rest were subjected to air overpressure equal to 1 and $3 \mathrm{~atm}$ for the period of 30 minutes and 3 hours. The swimming animals remained under a pressure of 1 and $3 \mathrm{~atm}$ for the period depending on their exercise capacity: 40 minutes for $1 \mathrm{~atm}$ and 20 minutes for $3 \mathrm{~atm}$.

The methodology for determining a.a.a. levels was described in a work previously published in "Medycyna Pracy" [13]. The control group consisted of rats that spent 1-3 hours in the experimental chamber at rest without the overpressure being applied.

\section{RESULTS}

The obtained results are presented in Table 1 and fig. 1 and 2 . 
Ascorbic acid content (a.a.) in adrenal glands of rats in hyperbaric air conditions

\begin{tabular}{|c|c|c|c|c|c|c|c|c|}
\hline \multirow[t]{2}{*}{ No. } & \multirow[t]{2}{*}{$\begin{array}{l}\text { Experimental } \\
\text { conditions }\end{array}$} & \multirow[t]{2}{*}{$\begin{array}{l}\text { Number of } \\
\text { rats }\end{array}$} & a.a. (mg) & \multirow[t]{2}{*}{$\begin{array}{l}\text { Standard } \\
\text { error }\end{array}$} & \multirow[t]{2}{*}{$t^{x}$} & $\begin{array}{l}\text { Weight of } \\
\text { adrenal } \\
\text { glands }\end{array}$ & \multirow[t]{2}{*}{$\begin{array}{l}\text { Standard } \\
\text { error }\end{array}$} & \multirow[t]{2}{*}{$t^{x}$} \\
\hline & & & $\begin{array}{ll}100 \mathrm{~g} & \text { of } \\
\text { adrenal } & \\
\text { glands } & \end{array}$ & & & $\begin{array}{l}100 \mathrm{~g} \text { of } \\
\text { body } \\
\text { weight }\end{array}$ & & \\
\hline 1 & $\begin{array}{l}\text { Control group } \\
\mathrm{xx}\end{array}$ & 18 & $369 \pm 75.2$ & 17.9 & - & 17.6 & 0.28 & - \\
\hline 2 & $1 \mathrm{~atm} 30^{\prime}$ rest & 12 & $253 \pm 50.6$ & 14.6 & $5.02>t$ & 18.2 & 1.26 & $0.385<t$ \\
\hline 3 & $1 \mathrm{~atm} 3^{\mathrm{h}}$ rest & 9 & $305 \pm 50.3$ & 16.7 & $2.61>t$ & 17.1 & 0.27 & $0.397<t$ \\
\hline 4 & $3 \mathrm{~atm} 30^{\prime}$ rest & 8 & $250 \pm 62.4$ & 20.9 & $4.34>t$ & 17.7 & 0.29 & $0.077<\mathrm{t}$ \\
\hline 5 & $3 \mathrm{~atm} 3^{\mathrm{h}}$ rest & 8 & $387 \pm 79.8$ & 28.2 & $0.53<t$ & 17.7 & 1.26 & $0.069<\mathrm{t}$ \\
\hline 6 & $\begin{array}{l}1 \text { atm ca.40' } \\
\text { effort }\end{array}$ & 7 & $294 \pm 27.5$ & 10.4 & $3.62>t$ & 17.4 & 0.23 & $0.198<t$ \\
\hline 7 & $\begin{array}{l}3 \text { atm ca. } 20^{\prime} \\
\text { effort }\end{array}$ & 8 & $315 \pm 62.0$ & 21.9 & $1.91<t$ & 16.1 & 0.26 & $1.23<t$ \\
\hline
\end{tabular}

$\mathrm{x}$ - statistical variability in the Student's t test

$\mathrm{xx}$ - the animals placed in conditions analogous to the rest of the group, with the exception of overpressure

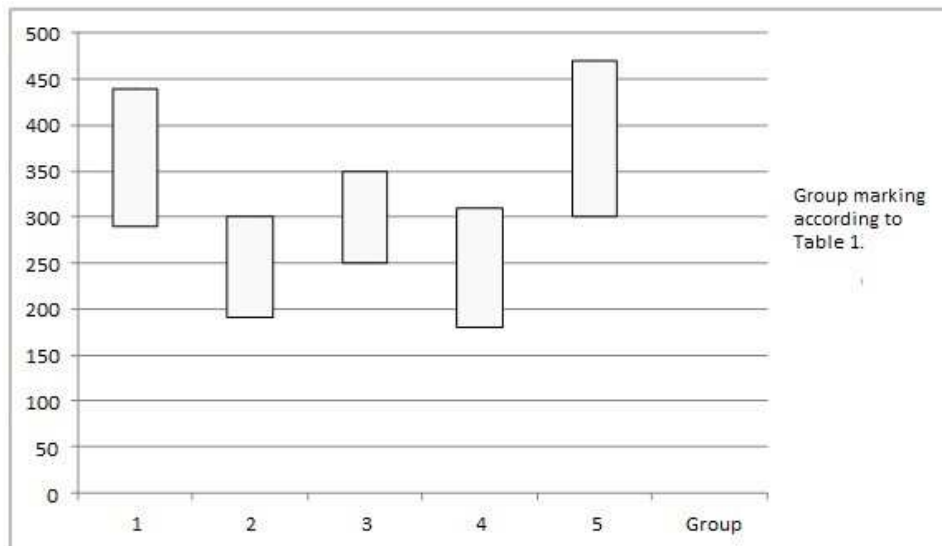

Fig. 1 The a.a.a. content of rats in the rest groups (in milligrams per $100 \mathrm{~g}$ of adrenal glands taking into account the average error of the arithmetic mean). Rys.1 Zawartość n.k.a. u szczurów w grupach spoczynkowych (w miligramach na 100 g nadnerczy z uwzględnieniem średniego błędu średniej arytmetycznej).

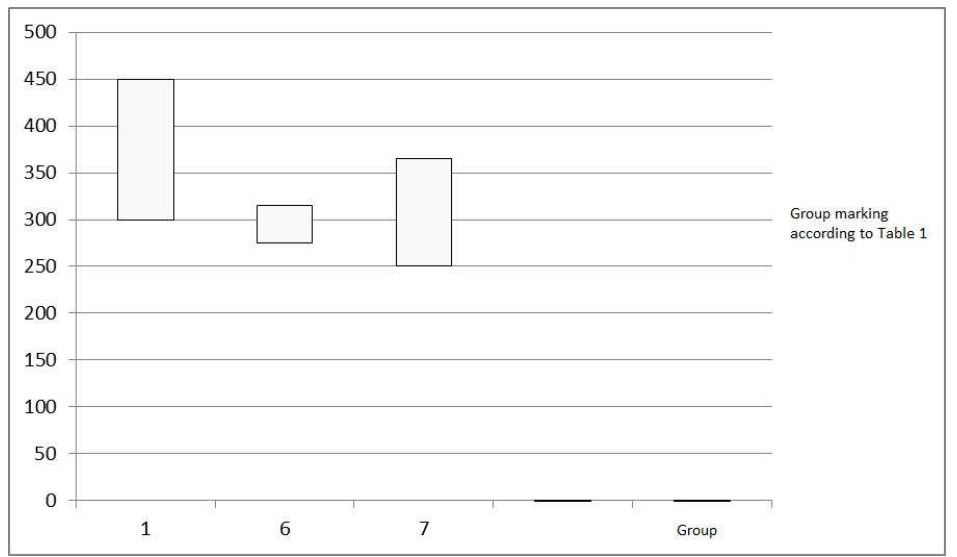

Fig. 2 The a.a.a. content of the rats in groups burdened with physical effort (see above).

Rys. 2 Zawartość n.k.a. u szczurów w grupach obciążonych wysiłkiem (j.w.). 
W grupach spoczynkowych (grupy 2 i 4 na rys. 1) eksponowanych przez 30 minut na ciśnienie 1 i 3 atn obserwowano znamienne statystycznie obniżenie n.k.a., natomiast przy czasie ekspozycji 3 godziny (grupa 3 na rys. 1) - przy ciśnieniu 1 atn obserwowano obniżenie, zaś przy 3 atn (grupa 5) stężenie n.k.a. nie różniło się od normy (grupa 1). W grupie obciążonej wysiłkiem przez 40 minut przy 1 atn (grupa 6 na rys. 2) obserwowano obniżenie, - n.k.a. pozostawał w granicach normy.

\section{DYSKUSJA}

Badania n.k.a. u szczurów w warunkach obciążenia wysiłkiem wyczerpującym, lecz bez zastosowania hiperbarii $[14,15]$ wykazały jego obniżenie dopiero po 75 minutach lub przy wyczerpaniu, co następowało średnio po 200 minutach, zaś n.k.a. obniżał się wówczas o ok. 50\%. Natomiast w naszych badaniach zastosowanie hiperbarii rzędu 1 atn przez czas 30 minut dawało już wyraźny spadek n.k.a. W przeprowadzonych przez nas poprzednio badaniach [7] wykazano, że hiperbaria tlenowa ma wpływ na obniżenie podobne nawet przy czasie pływania znacznie krótszym.

Jeżeli uwzględnić to, że grupy badane różniły się od kontrolnych tylko oddziaływaniem hiperbarii lub rodzajem mieszaniny oddechowej przy tym samym nadciśnieniu i że obserwowano u nich spadek n.k.a. już przy krótkotrwałej ekspozycji,przyjmujemy, że zmiana ta zachodziła $\mathrm{w}$ wyniku reakcji stresowej $\mathrm{w}$ warunkach hiperbarii. Chociaż trudno na podstawie uzyskanych wyników badania n.k.a. ocenić natężenie stresu jak to proponowali różni autorzy $[6,11,12,15,16,17,19,20)$, to jednak nie można bez dalszych badań odrzucić twierdzenia, że hiperbaria działa jako jeden ze stresorów zaś obserwowany spadek n.k.a. może stanowić jeden z objawów ogólnej reakcji alarmowej.

Przy badaniach oddziaływania samej hiperbarii bez wysiłku, wyniki uzyskiwane przez innych autorów nie były jednoznaczne. Aschan [1] stwierdził, że oddychanie tlenem przy 1 ata już po 2 godzinach daje znaczny spadek n.k.a., czego nie potwierdziły badania Gerschman i Fenna $[9,10]$, zdaniem których spadek ten następował dopiero w okresie zatrucia po 2-3 dniach. Poddanie zwierząt hiperbarii rzędu 5-6 atn przy krótkotrwałej ekspozycji dawało większe obniżenie n.k.a. przy oddychaniu powietrzem niż tlenem, co wiążą oni ze stresem ciśnieniowym. Nasze badania przy ciśnieniach 1-3 atn powietrza a w poprzedniej pracy i tlenu [13] danych tych nie potwierdziły, gdyż spadek był w obu przypadkach podobny. Zastosowanie dłuższych ekspozycji w hiperbarii pozwoliło jednak częściowo zróżnicować działanie tych czynników.

W grupie poddanej 3 atn powietrza zawartość n.k.a. obniżona po pół-godzinnej hiperbarii wracała do normy w czasie 3 godzinnej ekspozycji. Wytłumaczenie tego faktu wymaga dalszych badań. W grupie poddanej 3 atn hiperbarii tlenowej zawartość n.k.a. po 3 godzinach utrzymywała się na równie niskim poziomie jak przy 30 minutach [12]. Trudny do wyjaśnienia wydaje się fakt, że przy 3 atn powietrza po 20 minutowym wysiłku poziom n.k.a. pozostawał w normie. Być może, czas ekspozycji był zbyt krótki (20 minut) aby wystąpił znamienny spadek zawartości n.k.a. [12,20]. Ponadto działał tu tylko jeden czynnik stresujący w postaci hiperbarii bez dodatkowego oddziaływania tlenu.

Można by przyjąć, że o ile spadek n.k.a. podczas
In the rest groups (groups 2 and 4 in Fig. 1) exposed for 30 minutes to a pressure of 1 and 3 atn, a statistically significant reduction was observed, while with the exposure time of 3 hours (group 3 in Fig.1) - at a pressure of 1 atn, a decrease was observed, and at 3 atm (group 5), the a.a.a. concentration did not differ from normal (group 1). In the group burdened with effort for 40 minutes at $1 \mathrm{~atm}$ (group 6 in Fig. 2) a decrease was observed - the a.a.a. remained within the normal range.

\section{DISCUSSION}

Research into the a.a.a. level in rats subjected to exhaustive effort, without the application of hyperbaric conditions $[14,15]$ showed its reduction as late as 75 minutes into the exposure or when exhausted, which occurred on average after the lapse of 200 minutes with the a.a.a. being then decreased by approximately $50 \%$. However, in our studies the application of hyperbaria of $1 \mathrm{~atm}$ for 30 minutes demonstrated a clear decrease in the a.a.a. Our previous studies [7] demonstrated that hyperbaric oxygenation produced a similar reduction even when the swimming time is significantly shorter.

If we take into account the fact that the test groups differed from the control groups only by the effect of hyperbaria or the type of breathing mixture used, while the overpressure was the same and that the decrease in a.a.a. was observed already during a short-term exposure, we may assume that this change occurred as a result of a stress reaction in hyperbaric conditions. Although it is difficult to assess the stress intensity on the basis of the results obtained for a.a.a., as was suggested by different authors $[6,11,12,15,16,17,19,20]$, it is also impossible to reject, without further research, the theory that hyperbaria acts as one of the stressors and the observed decrease in the a.a.a. may be one of the symptoms of a general alarm reaction.

When testing the impact of hyperbaria alone, without the imposed physical effort, the results obtained by other authors were not conclusive. Aschan [1] stated that breathing with oxygen at 1 ata after only 2 hours gives a significant decrease in a.a.a., which was not confirmed by the studies of Gerschman and Fenna [9,10], according to which such a drop occurred only after 2-3 days of poisoning. Subjecting the animals to hyperbaric conditions at 5-6 atm for a short period of time resulted in a greater reduction of a.a.a. when breathing with air rather than oxygen, which they associate with the pressure stress. Our tests conducted with air pressures of 1-3 atn, and in the previous work also with the use of pressurised oxygen [13], did not confirm these data, as the drop in both cases was similar. Nonetheless, the application of longer hyperbaric exposures allowed to partially differentiate the effects of these factors.

In the group subjected to air at 3 atm the a.a.a. content, which reduced after 30 minutes spent in hyperbaric conditions, returned to a normal level during the 3-hour exposure. An explanation of this fact requires further research. In the group subjected to hyperbaric oxygenation at $3 \mathrm{~atm}$ for 3 hours, the a.a.a. content remained at an equally low level as at 30 minutes [12]. The fact that seems difficult to explain is that at $3 \mathrm{~atm}$ of air after 20 minutes of effort, the level of a.a.a. was normal. Perhaps the exposure time was too short [20] minutes) to note a significant decrease in the content of a.a.a. $[12,20]$. Moreover, only a single stress factor was 
krótkotrwałych ekspozycji zależał od stresu ciśnieniowego, to przy dłuższym działaniu ujawniał się specyficzny wpływ hiperbarii tlenowej [10]. Zgodne to jest $\mathrm{z}$ twierdzeniem [16,17], że sekrecja korowonadnerczowa może pozostać wysoka w całym okresie działania stresora, jeżeli zwierzę nie może się do niego zaadoptować.

Hiperbaria tlenowa jest stresem nie spotykanym w normalnym rozwoju filogenetycznym i nie można bez zastrzeżeń przyjąć twierdzenia, że wzmożenie sekrecji jest tu zjawiskiem czysto obronnym. Bean [3,4] stwierdził, że eliminacja osi korowo-nadnerczowej chroni zwierzę przed działaniem hiperbarii tlenowej, natomiast wszelkie warunki zwiększające tkankowe zużycie tlenu, co ma miejsce m.in. przy wzmożonym wydzielaniu hormonów nadnerczy, skracają czas przeżycia zwierzęcia. Możliwe, że hiperbaria a w szczególności hiperbaria tlenowa stanowi silny czynnik stresujący, który zwłaszcza w niekorzystnych warunkach ujawnia swoje działanie nawet $\mathrm{w}$ zakresie ciśnienia przyjmowanym za obojętne dla ustroju [18].

\section{WNIOSKI}

1. Krótkotrwała (30 minut) ekspozycja szczura na hiperbarię powoduje obniżenie zawartości n.k.a.

2. Przy przedłużonej (3-godzinnej) ekspozycji na 3 atn powietrza zawartość n.k.a. wraca do normy.

3. Obniżenie zawartości n.k.a. wskazuje na występowanie u szczura stresu $\mathrm{w}$ warunkach hiperbarii, jednak nie pozwala na określenie jego natężenia stosowaną w badaniu metodą. present in the form of hyperbaria without an additional influence of oxygen.

One could assume that as far as the drop in a.a.a. during short-term exposures depended on pressure stress, a prolonged exposure allowed to reveal the specific effect of hyperbaric oxygenation [10]. This is consistent with the hypothesis $[16,17]$ that corticoadrenal secretion may remain high throughout the time of the stressor's activity if an animal is unable to adapt to it.

Hyperbaric oxygenation constitutes a stress that is not found in regular phylogenetic development, and the theory that an increase in the secretion is a purely defensive phenomenon cannot be accepted without a reservation. Bean $[3,4]$ affirmed that the elimination of the cortical-adrenal axis protects an animal against the effects of hyperbaric oxygenation, whilst any conditions that increase tissue oxygen consumption, which occurs, inter alia, in the case of an increased secretion of adrenal hormones, shortens the survival time of an animal. It is possible that hyperbaria, and in particular hyperbaric oxygenation, constitutes a strong stress factor which, especially in unfavourable conditions, reveals its effects even within the pressure range assumed to be inert in the body [18].

\section{Conclusions}

1. It was found that a short-term exposure (30 minutes) of a rat to hyperbaric conditions causes a decrease in the content of a.a.a.

2. With a prolonged (3-hour) exposure to air at $3 \mathrm{~atm}$ the a.a.a. content returns to a normal level.

3. A reduction in the a.a.a. content indicates the presence of stress in hyperbaric conditions in the rat, however, it does not allow to determine its intensity with the method used in the study.

\section{REFERENCES}

Aschan G.: "Oxygen deficiency and oxygen poisoning as stress factors". Acta Soc.Med.Upsal.58, 265-268, 1953;

Bagramian E.R.: "O wlijanii narkoza na reakciju gipofizo-nadpoczecznikowoj sistiemy na naprjażenijo", Farmakoł. Toksikoł., 27, 335-338, 1964.

Bean J.W. Johnson P.C.: Am.J.Physiol., 179, 410-414, 1954;

Bean J.W.: "Tris buffer, CO2 and sympatho-adrenal system in reactions to O2 at high pressure", Am.J.Physiol., 201, 737-739, 1961;

Boulouard R.: "Effects of cold and starvation on adrenocartical activity of rats", Fed.Proc., 22, 750-754, 1963;

Charvat J.: "Steroid hormones", PZWL, Warsaw 1953;

Doboszyński T., Łokucijewski B.: Biul. Inst. Med. Mor., 17, 311-320, 1966;

Doboszyński T., Łokucijewski B.: "Ekspierymentalnoje issledowania wlijanija wysokogo dawlenia kisłoroda". II Międzynarodowe Sympozjum Medycyny Morskiej, Gdynia 1965;

Fenn W.O.: "Psychological effects of high pressures of nitrogen and oxygen", Circulation, 26, 1134-1143, 1962

10. Gerschman R., Fenn W.O.: "Ascorbic acid content of adrenal inoxygen poisoning", Am.J.Physiol., 171, 726, 1952;

11. Gerschman R., Fenn W.O.: "Ascorbic acid content of adrenal inoxygen poisoning", Am.J.Physiol., 176, 6-8, 1954,

12. Jamieson D., Brenk H.A.S.:"The effects of antioxidants at high pressure oxygen toxicity", Biochem. Pharmacol., 13, 159-164, 1964;

13. Kołpakow M.G.: Nadpoczeczniki i reanimacija, Medicina, Moscow 1964;

14. Łokucijewski B., Doboszyński T.: "The effect of hyperbaric oxygenation on ascorbic acid content in the adrenal glands of rats", Med.Pracy, 18, 484-8, 1967;

15. Namysłowski L.: "The results of further observations on the behaviour of ascorbic acid in adrenal glands of rats under the influence of physical effort", Roczn. PZH, 8, 79-80, 1957;

16. Namysłowski L.: "The effect of physical effort on ascorbic acid content in adrenal glands of rats", Roczn. PZH, 7, 425-433, 1956;

17. Pankow J.A.: "Niekotoryje dannyje ob. Imienienii funkcji kory nad pocecznikow u żywotnych w processie razwitja sostojanija naprażenja (stress)", Probl.Endokrin.Gormonoter., 9, 6, 3-6, 1963;

18. Paré W.P.:"The effect of chronic environmental stress on stomach ulceration, adrenal function and consummatory behaviour in the rat", J.Psychol., 57, 143-151, 1964;

19. Ryłowa M.Ł.: Mietody issledowanija chroniczeskiego dejstwia wrednych faktorow sredy w eksperimentie, Medicina, Leningrad, 1964;

20. Sayers G., Sayers M., Lewis H.L., Long C.N.H.: "Effect of adrenotropi hormone on ascorbic acid and cholesterol content of the adrenal", Proc. Soc. Exp. Biol. Med., 55, 238-239, 1944;

21. Sayers G., Sayers M.: "Regulation of pituitary adrenocorticotropin activity during the response of the rat to acute stress", Endocrinology, 40 , 265-273, 1947 